\section{Genetic Relationship and Diversity in Some Ornamental Palms Based on Proteins and Randomly Amplified Polymorphic DNA Markers}

\author{
Antar Nasr El-Banna ${ }^{1}$ \\ Genetics Department, Faculty of Agriculture, Kafrelsheikh University, Kafr \\ El-Sheikh, 33516, Egypt
}

Mohammed Elsayed El-Mahrouk

Horticulture Department, Faculty of Agriculture, Kafrelsheikh University, Kafr El-Sheikh, 33516, Egypt

\begin{abstract}
Mohammed Eraky El-Denary
Potato and Propagated Vegetables Research Department, Horticulture Research Institute, Agricultural Research Center, Giza 12619, Egypt
\end{abstract}

Yaser Hassan Dewir

Department of Horticulture, Faculty of Agriculture, Kafrelsheikh University, Kafr El-Sheikh, 33516, Egypt; and Plant Production Department, Faculty of Food \& Agriculture Sciences, King Saud University, P.O. Box 2460, Riyadh 11451, Saudi Arabia

\section{Yougasphree Naidoo}

School of Life Sciences, University of KwaZulu-Natal, Westville Campus, Private Bag X54001, Durban 4000, South Africa

Additional index words. ornamental palms, genetic relationships, RAPD, protein SDS PAGE, polymorphism

Abstract. For the first time, genetic diversity among 14 ornamental palm accessions originating from different countries and grown in different regions in Egypt were examined. Identification of genetic variation and phylogenetic relationships in ornamental palms would be useful for its genetic identification, improvement, and conservation. Genetic polymorphism was analyzed using the randomly amplified polymorphic DNA (RAPD) as well as protein markers. The electrophoretic pattern of protein analysis produced 21 bands distributed in all accessions with molecular sizes ranging from 11.8 to 99.3 KDa. Some accessions possessed some bands, which were absent in other accessions and could be used for their identification. Furthermore, 10 RAPD selected primers were employed to determine genetic variation among the 14 palm genotypes as well as to test the effectiveness of RAPD primers as a genetic marker. RAPD analysis revealed a high level of polymorphism $(\mathbf{1 0 0 \%})$ among the studied accessions. A total number of 310 amplified bands were generated across the studied genotypes with an average of 30 bands per primer. Cluster analysis using sequence alignment was done to generate a dendrogram verifying the relationship among the 14 studied ornamental palms, with an average similarity matrix range of 0.00 to 0.08 and 0.39 to 0.93 for RAPD and protein markers, respectively. It is concluded that, both SDS-protein and RAPD markers are equally important for genetic analysis and are suitable for the characterization of ornamental palm collection. tropical, subtropical, and the warm climates of the world. Most palms are characterized by their large evergreen leaves but there are many exceptions. Palms exhibit an enormous diversity in physical characteristics despite their similarity in shape. Many palms serve for different landscaping purposes due to their exotic appearance. They are used in the landscape as unique specimens, border plants, patio trees, and street plantings. Specimen plants used individually have a distinctive or majestic quality that attracts immediate interest. Beside their ornamental values, they constitute the most important plants in arid and desert areas. Based on traditional markers, like growth habit, breeding behavior and other morphological characters, palms are classified as tall, dwarf, and intermediate types. Previous studies used morphological traits, mainly fruit characters (Foale, 1987; Kumaran et al., 2000) and isozymes (Carpio, 1982) to assess variation in ornamental palms. But, morphological markers are limited in number and not reliable due to environmental variables. On the other hand, protein or genetic analysis is promising tools for determination of taxonomic identities and relations as well as authentication of species. Especially genetic analysis may support the development of a comprehensive database of genetic variability between the species. Protein electrophoresis markers are predominant because they are less influenced by environmental conditions. They are codominant, without epistatic and pleotropic effects and are interpretable as genes and loci. Molecular markers, which detect variation at the DNA level overcome most of the limitations of morphological and biochemical markers. As demonstrated by their use in various plant species, molecular markers are best suited for estimation of genetic diversity and varietal identification. Besides their unlimited numbers, molecular markers are unaffected by environmental and developmental stage. Use of molecular markers gains further importance for perennial and recalcitrant crops like ornamental palms. RAPD permits the identification of taxa and the determination of phylogenetic relationships and intraspecific diversity at a genetic level (Williams et al., 1990).
Palms are flowering plants belonging to the family Arecaceae within the class of monocots. They are classified into 181 genera and roughly 2600 currently known species of ornamental palms (Christenhusz and Byng, 2016), most of which are restricted to the

Received for publication 25 May 2016. Accepted for publication 31 Oct. 2016.

The authors extend their appreciation to the International Scientific Partnership Program ISPP at King Saud University for funding this research work through (ISPP\# 0064)

${ }^{1}$ Corresponding author. E-mail: antarsalem@yahoo.com.
Table 1. List of accessions scientific names, collection site, and country of origin.

\begin{tabular}{clllc}
\hline No. & \multicolumn{1}{c}{ Scientific name } & Collection site & \multicolumn{1}{c}{ Country of origin } & No. of palms \\
\hline 1 & Rhapis excelsa & Alexandria & China & 3 \\
2 & Bismarckia nobilis & Cairo & Madagascar & 3 \\
3 & Brahea armata & Alexandria & Baja California & 3 \\
4 & Archontophoenix purpurea & Giza & Queensland, Australia & 3 \\
5 & Dypsis decaryi & Giza & Madagascar & 3 \\
6 & Chamaedorea elegans & Tanta & Southern Mexico & 3 \\
7 & Sabal palmetto & Tanta & Cuba & 3 \\
8 & Areca vestiaria & Giza & North Sulawesi & 3 \\
9 & Phoenix dactylifera & Tanta & Iraq & 3 \\
10 & Roystonea regia & Monyfia & Southern Florida & 3 \\
11 & Wodyetia bifurcata & Giza & Australia & 3 \\
12 & Livistona chinensis & Tanta & Southern Japan, Taiwan & 3 \\
13 & Washingtonia filifera & Tanta & Southwestern North America & 3 \\
14 & Phoenix roebelenii & Alexandria & Southwestern China & 3 \\
\hline
\end{tabular}


Table 2. Primers, their respective base sequences, number of amplified bands, number of polymorphic bands, and polymorphism percentages for the ornamental palms analyzed.

\begin{tabular}{|c|c|c|c|c|c|}
\hline Primer no. & Primer name & Primer sequence & Total band no. & Polymorphic bands & Polymorphism \% \\
\hline$\overline{\mathrm{P} 1}$ & B-02 & $5^{\prime}$-TGATCCCTGG-3' & 23 & 23 & 100 \\
\hline $\mathrm{P} 2$ & B-20 & $5^{\prime}-\mathrm{GGACCATTAC-3'}$ & 34 & 34 & 100 \\
\hline P3 & A-05 & 5'-AGGGGTCTTG-3' & 27 & 27 & 100 \\
\hline $\mathrm{P} 4$ & G-09 & $5^{\prime}$-CTGACGTCAC-3' & 38 & 38 & 100 \\
\hline P5 & B-04 & $5^{\prime}$-GGACTGGAGT-3' & 26 & 26 & 100 \\
\hline P6 & E-10 & $5^{\prime}-\mathrm{CACCAGGTGA-3^{ \prime }}$ & 15 & 15 & 100 \\
\hline P7 & D-05 & $5^{\prime}$-TGAGCGGACA-3' & 40 & 40 & 100 \\
\hline P8 & A-17 & 5'-GACCGCTTGT-3' & 31 & 31 & 100 \\
\hline P9 & C-02 & 5'-GTGAGGCGTC-3' & 40 & 40 & 100 \\
\hline $\mathrm{P} 10$ & A-10 & 5'-GTGATCGCAG-3' & 36 & 36 & 100 \\
\hline
\end{tabular}

The RAPD technique has been successfully used in a number of taxonomic and genetic diversity studies (Rodriguez et al., 1999; Sultan et al., 2008; Upadhyay et al., 2004; Wolf et al., 1999) and proved suitable for use with ornamental palms (Sreekumar and Renuka, 2006). DNA-based techniques have been also designed to specify the observed diversity (Emoghene, 2015; Rhouma et al., 2007; Sreekumar and Renuka, 2006; Upadhyay et al., 2004). The objective of this study was to estimate the genetic diversity and genetic relationship among 14 accessions of ornamental palms using protein and RAPD markers.

\section{Materials and Methods}

Plant materials. Fourteen accessions of ornamental palms were collected from different areas in Egypt (Table 1). The plant accessions were grown in the ornamental nursery of El Kenana Company, Tanta, Egypt. Young and fresh leaf material was placed into sealed plastic bags and kept at $-80{ }^{\circ} \mathrm{C}$ until used for DNA and total protein extraction. The molecular analysis was carried out in the Genetics Department, Faculty of Agriculture, during 2014-15.

Protein extraction and electrophoresis. SDS-polyacrylamide gel electrophoresis (SDSPAGE) was carried out according to Laemmli (1970) as modified by Studier (1973). Protein was extracted by homogenizing 200-mg fresh leaf samples in $1 \mathrm{~mL}$ of $20 \%$ sucrose. Then the samples were centrifuged for $10 \mathrm{~min}$ at $10,000 \mathrm{rpm}$. The upper face was transferred to new tubes and kept at $-80{ }^{\circ} \mathrm{C}$ until use. Protein concentration was assessed using Pierce ${ }^{\mathrm{TM}}$ Coomassie (Bradford) Protein Assay Kit (Thermo Scientific, USA) according the manufacturer's recommendations. Protein samples ( $40 \mu \mathrm{g}$ each) were mixed with an equal volume of buffer containing $0.025 \mathrm{M}$ Tris- $\mathrm{HCl}, \mathrm{pH}$ 6.8, 4\% SDS, 20\% glycerol, $10 \% 2$ mercaptoethanol, and bromophenol blue. The prepared mixture was heated in a water bath for $5 \mathrm{~min}$ at $96{ }^{\circ} \mathrm{C}$. Protein samples were separated in $12 \%$ polyacrylamide gel electrophoresis. Protein bands were visualized using Coomassie blue dye.

Plant DNA extraction and RAPD-PCR condition. One-gram fresh leaves from three plants of each accession were grinded with liquid nitrogen and the genomic DNA was extracted using the modified cetyltrimethyl ammonium bromide protocol of Doyle and

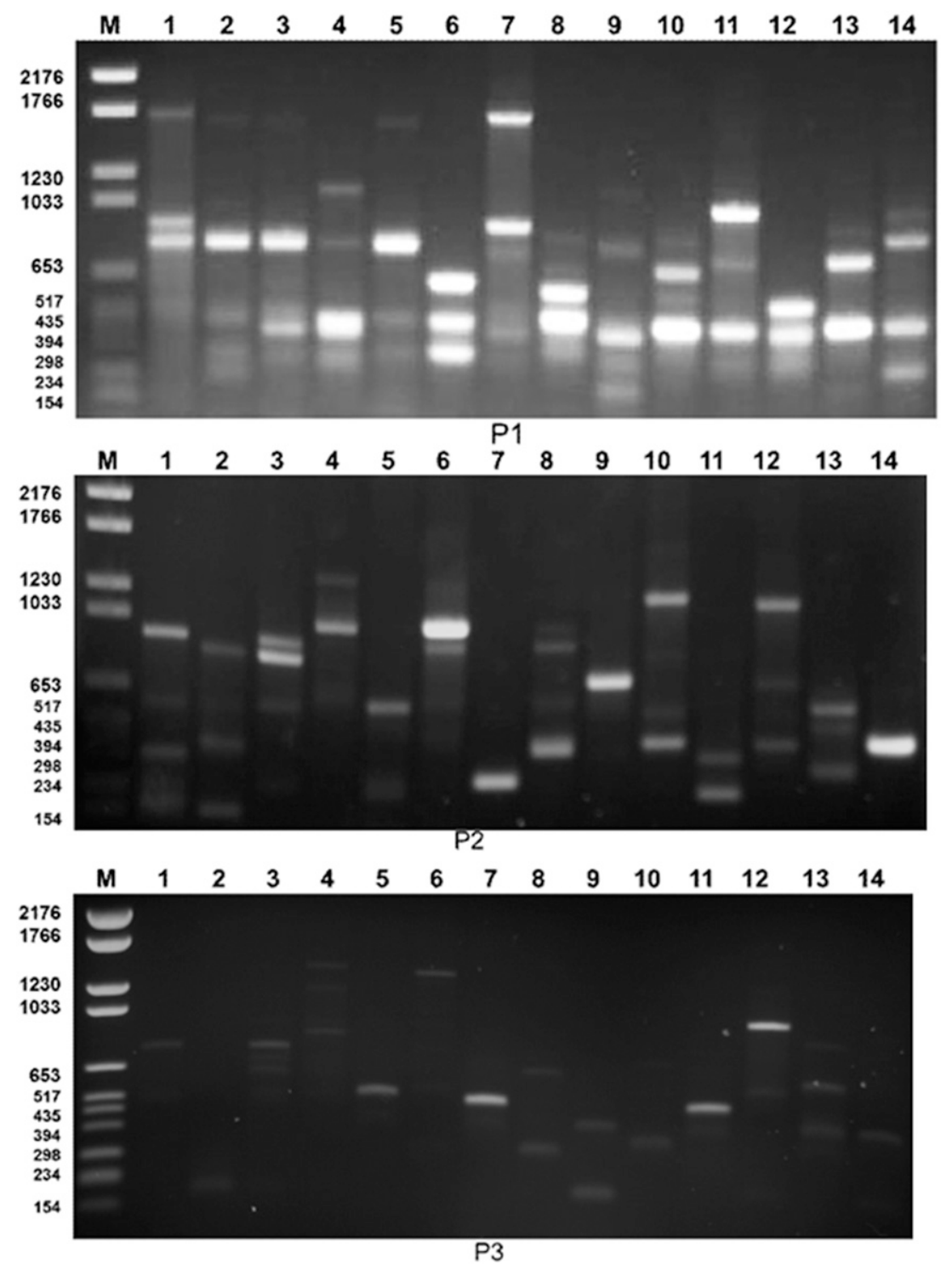

Fig. 1. Randomly amplified polymorphic DNA banding patterns of the 14 ornamental palm accessions using primers P1, P2, and P3. Lanes from 2 to 15 represent ornamental palm accessions nos. 1 to 14 , Lane 1: DNA marker $(1 \mathrm{~kb})$. Band sizes of the marker are expressed in $\mathrm{bp}$.

Doyle (1990). Polymerase chain reactions (PCRs) were conducted using 10 primers (10-mer primers) (GENET Bio, South Korea) with the sequences presented in Table 2. Amplification was carried out in $25-\mu \mathrm{L}$ reaction volume containing the following reagents: $1.0 \mu \mathrm{L}$ dNTPs (10 mM), $1.0 \mu \mathrm{L} \mathrm{MgCl}_{2}(25 \mathrm{~mm}), 5 \mu \mathrm{L}$ $10 \mathrm{X}$ buffer, $1.0 \mu \mathrm{L}$ primer $(10 \mathrm{pmol}), 1.0 \mu \mathrm{L}$
DNA ( $25 \mathrm{ng} / \mu \mathrm{L}), 0.3 \mu \mathrm{L}$ taq polymerase (5 unit $/ \mu \mathrm{L}$ ), and $15.7 \mu \mathrm{L} \mathrm{ddH}_{2} \mathrm{O}$. Amplification was carried out in an automated thermal cycler (MJ Mini; Bio Rad, Foster City, CA) as follows: one cycle at $94{ }^{\circ} \mathrm{C}$ for $5 \mathrm{~min}$ followed by 40 cycles at $95{ }^{\circ} \mathrm{C}$ for $1 \mathrm{~min}$; $35^{\circ} \mathrm{C}$ for $1 \mathrm{~min}$ and $72{ }^{\circ} \mathrm{C}$ for $2 \mathrm{~min}$. The reaction was finally incubated at $72{ }^{\circ} \mathrm{C}$ for 
Table 3. Similarity coefficient among the 14 ornamental palm accessions based on RAPD analysis.

\begin{tabular}{|c|c|c|c|c|c|c|c|c|c|c|c|c|c|c|}
\hline Genotypes & 1 & 2 & 3 & 4 & 5 & 6 & 7 & 8 & 9 & 10 & 11 & 12 & 13 & 14 \\
\hline 1 & 1.00 & & & & & & & & & & & & & \\
\hline 2 & 0.08 & 1.00 & & & & & & & & & & & & \\
\hline 3 & 0.04 & 0.02 & 1.00 & & & & & & & & & & & \\
\hline 4 & 0.00 & 0.00 & 0.06 & 1.00 & & & & & & & & & & \\
\hline 5 & 0.00 & 0.00 & 0.07 & 0.00 & 1.00 & & & & & & & & & \\
\hline 6 & 0.00 & 0.00 & 0.02 & 0.04 & 0.04 & 1.00 & & & & & & & & \\
\hline 7 & 0.00 & 0.04 & 0.04 & 0.06 & 0.05 & 0.02 & 1.00 & & & & & & & \\
\hline 8 & 0.02 & 0.00 & 0.02 & 0.00 & 0.06 & 0.03 & 0.04 & 1.00 & & & & & & \\
\hline 9 & 0.02 & 0.02 & 0.04 & 0.02 & 0.00 & 0.02 & 0.09 & 0.07 & 1.00 & & & & & \\
\hline 10 & 0.02 & 0.02 & 0.00 & 0.06 & 0.00 & 0.02 & 0.02 & 0.03 & 0.04 & 1.00 & & & & \\
\hline 11 & 0.04 & 0.02 & 0.02 & 0.02 & 0.02 & 0.00 & 0.02 & 0.11 & 0.05 & 0.02 & 1.00 & & & \\
\hline 12 & 0.00 & 0.00 & 0.00 & 0.03 & 0.00 & 0.03 & 0.02 & 0.05 & 0.00 & 0.03 & 0.05 & 1.00 & & \\
\hline 13 & 0.02 & 0.02 & 0.02 & 0.00 & 0.02 & 0.04 & 0.00 & 0.02 & 0.00 & 0.02 & 0.06 & 0.00 & 1.00 & \\
\hline 14 & 0.00 & 0.00 & 0.00 & 0.02 & 0.02 & 0.00 & 0.00 & 0.04 & 0.00 & 0.04 & 0.05 & 0.10 & 0.02 & 1.00 \\
\hline
\end{tabular}

$\mathrm{RAPD}=$ randomly amplified polymorphic DNA.

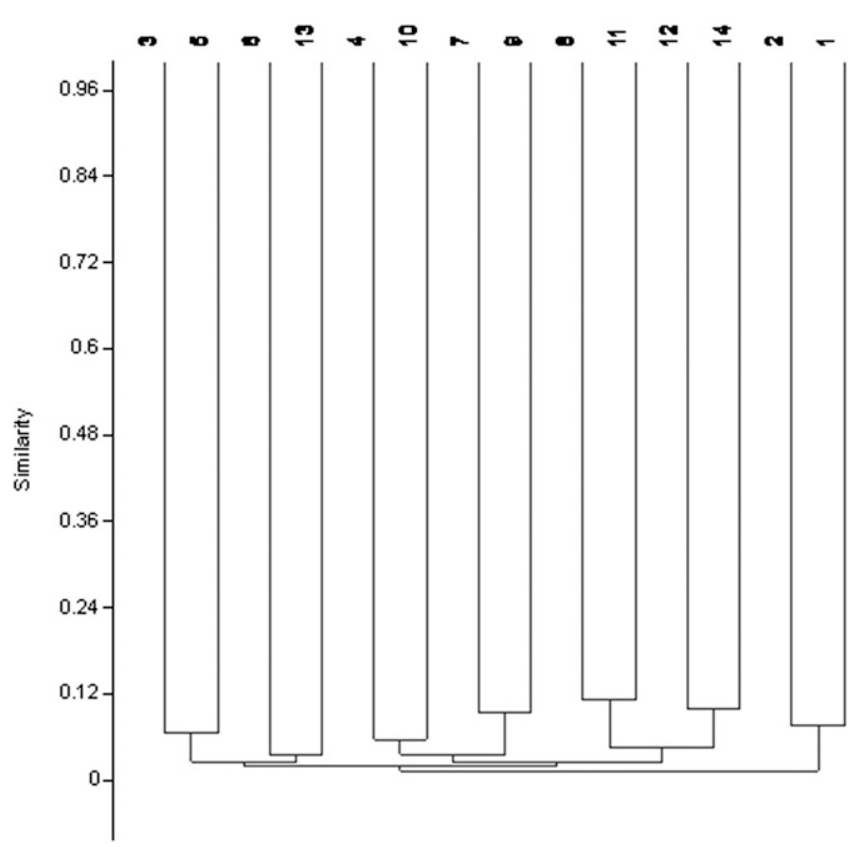

Fig. 2. Randomly amplified polymorphic DNA-based dendrogram of the 14 ornamental palms accessions constructed using unweighted pair-group method using arithmetic averages and similarity matrices.

7 min. The RAPD products were electrophoresed in $1.5 \%$ agarose gel in TAE buffer at $75 \mathrm{~V}$. The gel was stained with ethidium bromide and then distained with tap water and photographed using a gel documentation system (UVITEC; Cambridge Company, Cambridge, UK).

Data analysis. Amplification profiles generated by all the different RAPD primers as well as protein bands (three replicates) were scored as presence (1) and absence (0) of a band of a particular molecular size to compile a binary matrix which was then subjected to cluster analysis. Both faint and intense bands were scored if shown to be reproducible in separate runs. The similarity matrix was estimated using Jaccard's genetic similarity index (Jaccard, 1908). A dendrogram was generated by cluster analysis with the unweighted pair-group method using the arithmetic averages (UPGMA) (Jain and Dubes, 1988). PAST statistics software version 2.17 package was used to analyze the data (Hammer et al., 2003).

\section{Results and Discussion}

RAPD analysis. The 10 primers used in RAPD analysis produced reproducible and consistent banding patterns of the 14 accessions and generated a total of 310 bands which were all polymorphic (Table 2 ). There were 31 polymorphic bands per primer on average. Examples of polymorphism are shown in Fig. 1. Among the primers used, primer E-10 produced the lowest number of bands (15), whereas primers C-02 and D-05 generated the highest number (40). All 14 accessions were distinguishable by their band patterns. RAPD technique proved effective for identifying accessions of palm, although the overall exhibited polymorphism is rather high in comparison with results reported for other cultivated species ( $\mathrm{Hu}$ and Quiros, 1991; Mossler et al., 1992; Wolff and Peters-van Rijn, 1993), and even date palm cultivars (Khierallah et al., 2014). Therefore, RAPD markers are useful for ornamental palm germplasm characterization and genetic maintenance. The 310 RAPDs were used to estimate relationships among the accessions. The similarity coefficient based on RAPD patterns ranged from 0.00 to 0.11 (Table 3 ). Hence, genetic similarity between palm accessions varied from $0.00 \%$ to $11.0 \%$. The highest similarity value $(11 \%)$ was between accession nos. 8 and 11. A dendrogram constructed by UPGMA cluster analysis using RAPD-based genetic distance is presented in Fig. 2. The overall tree topology suggested a rather weak grouping association. However, morphologically similar varieties were clustered together. It is notable that most of the cultivars from the same origin were associated. Generally, there was a distinct pattern of bands amplified from each accession irrespective of its origin, although some bands were shared among the accessions. Both intense and faint bands were produced (Fig. 1). There is overlapping of clusters which group the palm accessions regardless of their origin. The dendrogram can be divided into two distinct clusters. The first contained the accessions nos. 1 and 2 that showed more divergence and individuality in their banding outline compared with the other accessions. The second cluster is divided into three subcluster. The first subcluster consisted of accessions nos. 3, 5, 6, and 13; the second accessions nos. $4,10,7$, and 9 ; and the third accessions nos. $8,11,12$, and 14 . The aforementioned subclusters were further divided into groups having a high degree of similarity. The results obtained in this study revealed that RAPD analysis is an easy, lowcost, and quick method for the identification of ornamental palms and could in addition improve the knowledge of genetic affinity. The variation in the number of bands amplified by different primers was influenced by variable factors such as primer structure, template quantity, and less number of annealing sites in the genome. The results of this study showed clear and high yields of amplified DNA fragments and high polymorphism $(100 \%)$ among accessions. In contrast, Hussein et al. (2004) and Adawy et al. (2004) reported low RAPD polymorphism in Egyptian date palm cultivars $(25.2 \%$ and $18.9 \%$, respectively). Meanwhile, Moghaieb et al. (2010), as well as Marsafari and Mehrabi (2013) reported relatively high RAPD polymorphism $(60.2 \%$ and $92.4 \%)$, respectively. Using RAPD 
Table 4. Protein banding profile of the 14 ornamental palm accessions (shaded boxes: band present, white boxes: band absent)

\begin{tabular}{|c|c|c|c|c|c|c|c|c|c|c|c|c|c|c|}
\hline \hline \multicolumn{10}{|c|}{ Genotypes } \\
\hline Protein bands (KDa) & 1 & 2 & 3 & 4 & 5 & 6 & 7 & 8 & 9 & 10 & 11 & 12 & 13 & 14 \\
\hline 99.1 & & & & & & & & & & & & & & \\
\hline 88.7 & & & & & & & & & & & & & & \\
\hline 74.6 & & & & & & & & & & & & & & \\
\hline 63.5 & & & & & & & & & & & & & & \\
\hline 52.3 & & & & & & & & & & & & & & \\
\hline 48.1 & & & & & & & & & & & & & & \\
\hline 44.5 & & & & & & & & & & & & & & \\
\hline 41.6 & & & & & & & & & & & & & & \\
\hline 39.2 & & & & & & & & & & & & & & \\
\hline 36.5 & & & & & & & & & & & & & & \\
\hline 34.4 & & & & & & & & & & & & & & \\
\hline 31.5 & & & & & & & & & & & & & & \\
\hline 27.7 & & & & & & & & & & & & & & \\
\hline 25.4 & & & & & & & & & & & & & & \\
\hline 22.3 & & & & & & & & & & & & & & \\
\hline 21.1 & & & & & & & & & & & & & & \\
\hline 18.4 & & & & & & & & & & & & & & \\
\hline 16.9 & & & & & & & & & & & & & & \\
\hline 16.0 & & & & & & & & & & & & & & \\
\hline 14.7 & & & & & & & & & & & & & & \\
\hline 11.8 & & & & & & & & & & & & & \\
\hline
\end{tabular}

Table 5. Similarity coefficient among the 14 ornamental palm accessions based on protein analysis.

\begin{tabular}{lcccccccccccccr}
\hline Genotypes & 1 & 2 & 3 & 4 & 5 & 6 & 7 & 8 & 9 & 10 & 11 & 12 & 13 & 14 \\
\hline 1 & 1.00 & & & & & & & & & & & & & \\
2 & 0.85 & 1.00 & & & & & & & & & & & \\
3 & 0.73 & 0.73 & 1.00 & & & & & & & & & & \\
4 & 0.64 & 0.64 & 0.79 & 1.00 & & & & & & & & & \\
5 & 0.47 & 0.47 & 0.67 & 0.59 & 1.00 & & & & & & & & \\
6 & 0.67 & 0.79 & 0.80 & 0.71 & 0.53 & 1.00 & & & & & & & & \\
7 & 0.73 & 0.73 & 0.87 & 0.79 & 0.58 & 0.93 & 1.00 & & & & & & & \\
8 & 0.47 & 0.47 & 0.67 & 0.59 & 0.88 & 0.53 & 0.58 & 1.00 & & & & & & \\
9 & 0.63 & 0.63 & 0.74 & 0.58 & 0.75 & 0.68 & 0.74 & 0.75 & 1.00 & & & & & \\
10 & 0.69 & 0.69 & 0.81 & 0.73 & 0.72 & 0.75 & 0.81 & 0.72 & 0.79 & 1.00 & & & & \\
11 & 0.47 & 0.39 & 0.59 & 0.60 & 0.81 & 0.53 & 0.59 & 0.81 & 0.68 & 0.65 & 1.00 & & & \\
12 & 0.71 & 0.71 & 0.82 & 0.65 & 0.65 & 0.76 & 0.82 & 0.65 & 0.89 & 0.88 & 0.58 & 1.00 & & \\
13 & 0.61 & 0.61 & 0.72 & 0.65 & 0.65 & 0.76 & 0.82 & 0.65 & 0.89 & 0.78 & 0.67 & 0.89 & 1.00 & \\
14 & 0.50 & 0.50 & 0.64 & 0.67 & 0.47 & 0.69 & 0.64 & 0.47 & 0.47 & 0.60 & 0.57 & 0.53 & 0.53 & 1.00 \\
\hline
\end{tabular}

primers, molecular markers for discrimination of various ornamental palms were developed in the present study. This germplasm has not yet been subjected to detailed molecular characterizations to develop useable markers. RAPD proved to be a powerful technique for the analysis of genetic diversity of date palm germplasm. Our results support previous findings by Sonboli et al. 2011 that RAPD markers are reliable for the identification of Dracocephalum species. They found high levels of polymorphism among species indicating the effectiveness of RAPD markers for evaluating intra- and interspecific genetic diversity in Dracocephalum.

Protein analysis. SDS protein banding patterns produced in total 21 bands with molecular sizes ranging from 11.8 to 99.1 $\mathrm{KDa}$, which were differentially distributed in ranged from 0.39 to 0.93 (Table 5). The highest similarity value $(93 \%)$ was between accession nos. 6 and 7, whereas the lowest value $(39 \%)$ was between accession nos. 2 and 11 . The UPGMA cluster analysis revealed that the 14 palm accessions could be divided into two major clusters. The first one contained the accession no. 14 and the second contained the rest, which is divided subsequently into three groups. The first group consisted of accessions nos. 1 and 2, whereas the second group contained the accessions nos. 5, 8 , and 11 . The third group is divided into two subgroups, one of them being the accession no. 4 and the other subgroup comprised accessions having a high degree of similarity (Fig. 3). SDS-PAGE technique has proven useful in supporting classical taxonomic studies (Abd El-Hady et al., 2010; Thanh et al., 2006). Protein markers are highly polymorphic and the environmental influence on their electrophoretic pattern is limited (Gepts et al., 1986). Protein markers have been used to study genetic diversity in many crops including Solanum spp. (El-Banna and Khatab, 2010; Mennella et al., 1999). Total protein markers were also extensively used for cultivar characterization (Mollema and Cole, 1996). Integration of different markers to study diversity allows a better discrimination betwee$\mathrm{n}$ accessions than a single method. However, although protein electrophoresis provides means of estimating genetic variation, many variations may still remain undetected at this level because only expressed genes can be detected. SDS-protein banding patterns produced some specific bands that were helpful to characterize and distinguish the studied ornamental palm accessions.

In conclusion, this study presented an efficient and simple procedure that can be used routinely to identify and categorize ornamental palm accessions, as well as to study the genetic diversity among ornamental palms that are difficult to classify based on their morphological traits and geographical origin.

\section{Literature Cited}

Abd El-Hady, A.E., A. Atef, and A.N. Haiba. 2010. Phylogenetic diversity and relationships of some tomato varieties by electrophoretic protein and RAPD analysis. J. Amer. Sci. 6:434441.

Adawy, S.S., E.H.A. Hussein, D. El-Khishin, M.M. Saker, A.A. Mohamed, and H.A. El-Itriby. 2004. Genotyping Egyptian date palm cultivars using RAPD, ISSR, AFLP markers and estimation of genetic stability among tissue culture derived plants. Arab J. Biotechnol. 8:99-114.

Carpio, C.B. 1982. Biochemical studies of Cocos nucifera L. Kalikasan. Philipp. J. Biol. 11:319338.

Christenhusz, M.J.M. and J.W. Byng. 2016. The number of known plants species in the world and its annual increase. Phytotaxa. Magnolia Press. 261:201-217.

Doyle, J.J. and J.L. Doyle. 1990. Isolation of plant DNA from fresh tissue. Focus 12:13-15.

El-Banna, A. and I. Khatab. 2013. Assessing genetic diversity of some potato (Solanum 


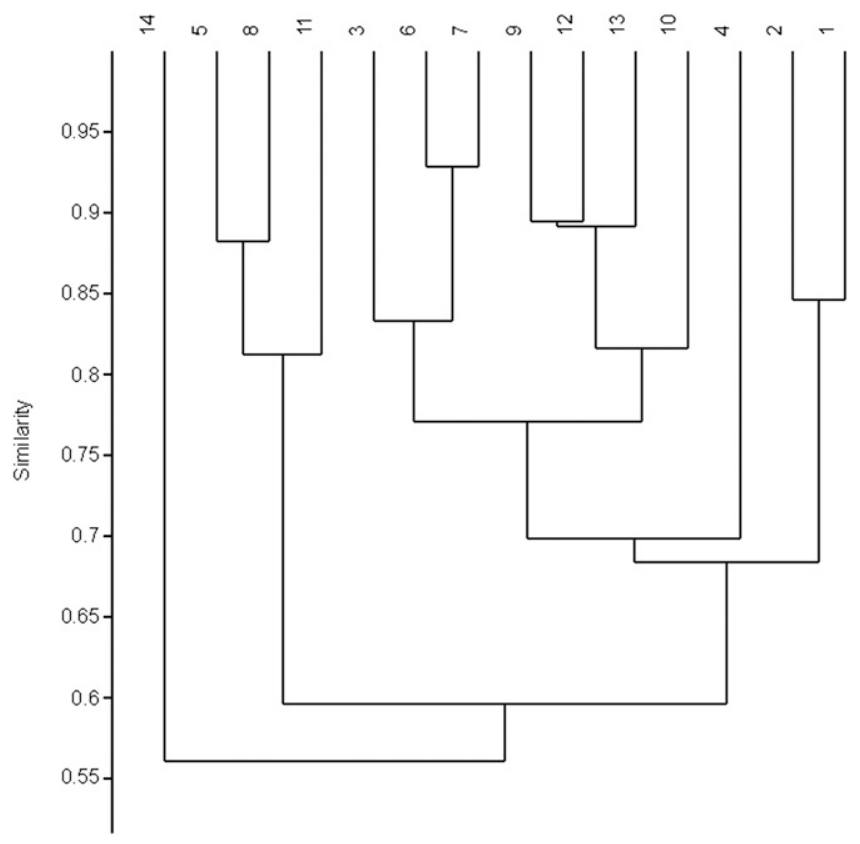

Fig. 3. Dendrogram showing genetic variability and relationships among the 14 ornamental palm accessions using protein marker.

tuberosum L.) cultivars by protein and RAPD markers. Egypt. J. Genet. Cytol. 42:89-101.

Emoghene, B.O., O. Asemota, M. Idu, and C.R. Eke. 2015. Molecular characterization of some date palms in Nigeria using RAPD markers. J. Appl. Biol. Biotechnol. 3:26-30.

Foale, M.A. 1987. Coconut germplasm in the South Pacific Islands. ACIAR Technical Report No. 4. Australian Centre for International Agricultural Research, Canberra.

Gepts, P., T. Osborne, K. Rashka, and F.A. Bliss. 1986. Phaseoline-protein variability in wild forms and landraces of the common bean (Phaseolus vulgare): Evidence for multiple centers of domestication. Econ. Bot. 40:451-468.

Hammer, Ø., D. Harper, and P. Ryan. 2003. Past: Palaeontological statistics software package for education and data analysis. Palaeontol. Electron. 4:1-9.

$\mathrm{Hu}$, J. and C.F. Quiros. 1991. Identification of broccoli and cauliflower cultivars with RAPD markers. Plant Cell Rpt. 10:505-511.

Hussein, E.H.A., S.S. Adawy, S.E.M. Ismail, and H.A. El-Itriby. 2004. Molecular characterization of some Egyptian date palm germplasm using RAPD and ISSR markers. Arab J. Biotechnol. 8:83-98.

Jaccard, P. 1908. Nouvel le srescherchessur la distribution florale. Bull. Soc. Vaud. Sci. Nat. 44:223-270
Jain, A.K. and R.C. Dubes. 1988. Algorithms for clustering data. Prentice-Hall advanced reference series. Prentice-Hall, Inc., Upper Saddle River, NJ.

Khierallah, H., S. Al-Sammarraie, and H. Mohammed. 2014. Molecular characterization of some Iraqi date palm cultivars using RAPD and ISSR markers. J. Asian Sci. Res. 4:490-503.

Kumaran, P.M., P.K. Koshy, V. Arunachalam, V. Niral, and V.A. Parthasarathy. 2000. Biometric clustering of coconut population of three Indian Ocean Islands, p. 16-18. In: N. Muraleedharan and R. Rajkumar (eds.) Recent advances in plantation crops research. Allied Publishers, New Delhi, India.

Laemmli, U.K. 1970. Cleavage of structural proteins during the assembly of the head of bacteriophage T4. Nature 227:680-685.

Marsafari, M. and A. Mehrabi. 2013. Molecular identification and genetic diversity of Iranian date palm (Phoenix dactylifera L.) cultivars using ISSR and RAPD markers. Austral. J. Crop Sci. 7:1160-1166

Mennella, G., V.O. Sanaja, L. Tonini, and V. Magnifico. 1999. Seed storage protein characterization of Solanum species and cultivars and androgenetic lines of $S$. melongena L. by SDS-PAGE and AE-HPLC. Seed Sci. Technol. 27:23-35. Ahmed, and A.G.M. Hassan. 2010. Genetic diversity and sex determination in date palms
Moghaieb, R.E.A., A.A. Abdel-Hadi, M.R.A.
(Phoenix dactylifera L.) based on DNA markers. Arab J. Biotechnol. 13:143-156.

Mollema, C. and R.A. Cole. 1996. Low aromatic acid concentrations in leaf proteins determines resistance to Frankliniella occidentalis in four vegetable crops. Entomol. Exp. Appl. 78:325-333.

Mossler, A., K.N. Egger, and G.A. Hughes. 1992. Low levels of genetic diversity in red pine confirmed by random amplified polymorphic DNA markers. Can. J. For. Res. 22:1332-1337.

Rhouma, S., S. Zehdi, A. Ould Mohamed Salem, A. Rhouma, M. Marrakchi, and M. Trifi. 2007. Genetic diversity in ecotypes of Tunisian datepalm (Phoenix dactylifera L.) assessed by AFLP markers. J. Hort. Sci. Biotechnol. 82:929-933.

Rodriguez, J.M., T. Berke, L. Engle, and J. Nienhuis. 1999. Variation among and within Capsicum species revealed by RAPD markers. Theor. Appl. Genet. 99:147-156.

Sonboli, A., A. Gholipour, M.H. Mirjalili, and M.A. Rad. 2011. Molecular characterization of Iranian Dracocephalum (Lamiaceae) species based on RAPD data. Acta Biol. Szeged. 55:227-230.

Sreekumar, V.B. and C. Renuka. 2006. Assessment of genetic diversity in Calamus thwaitesii BECC (Arecaceae) using RAPD markers. Biochem. Syst. Ecol. 34:397-405.

Studier, F.W. 1973. Analysis of Bacteriophage T7 early RNAs and proteins on slab gels. J. Mol. Biol. 79:237-248.

Sultan, P., A.S. Shawl, P.W. Ramteke, A. Kour, and P.H. Qazi. 2008. Assessment of diversity in Podophyllum hexandrum by genetic and phytochemical markers. Sci. Hort. 115:398408.

Thanh, V.C., P.V. Phuong, P.H. Vyen, and P.P. Hien. 2006. Application of protein electrophoresis SDS-PAGE to evaluate genetic purity and diversity of several varieties, International workshop in Agriculture, 20-21 Oct., Nong Lam University.

Upadhyay, A., K. Jayadev, R. Manimekalai, and V.A. Parthasarathy. 2004. Genetic relationship and diversity in Indian coconut accessions based on RAPD markers. Sci. Hort. 99:353-362.

Williams, J.G., A.R. Kubelik, K.J. Livak, J.A Rafalski, and S.V. Tingey. 1990. DNA polymorphisms amplified by arbitrary primers are useful as genetic markers. Nucleic Acids Res. 18:6531-6535.

Wolf, H.T., I. Zundorf, T. Winckler, R. Bauer, and T. Dingermann. 1999. Characterization of Echinacea species and detection of possible adulterations by RAPD analysis. Planta Med. 65:773-774

Wolff, K. and J. Peters-van Rijn. 1993. Rapid detection of genetic variability in chrysanthemum (Dendranthema grandiflora Tzvelev) using random primers. Heredity 71:335-341. 